\title{
Girl-Centered Participatory Assessment Tools
}

Kelly Hallman

Population Council

Follow this and additional works at: https://knowledgecommons.popcouncil.org/departments_sbsr-pgy

Part of the Family, Life Course, and Society Commons, Gender and Sexuality Commons, and the Indigenous Education Commons How does access to this work benefit you? Let us know!

\section{Recommended Citation}

Hallman, Kelly. 2019. "Girl-Centered Participatory Assessment Tools." New York: IMAGEN, GIRL Center. 


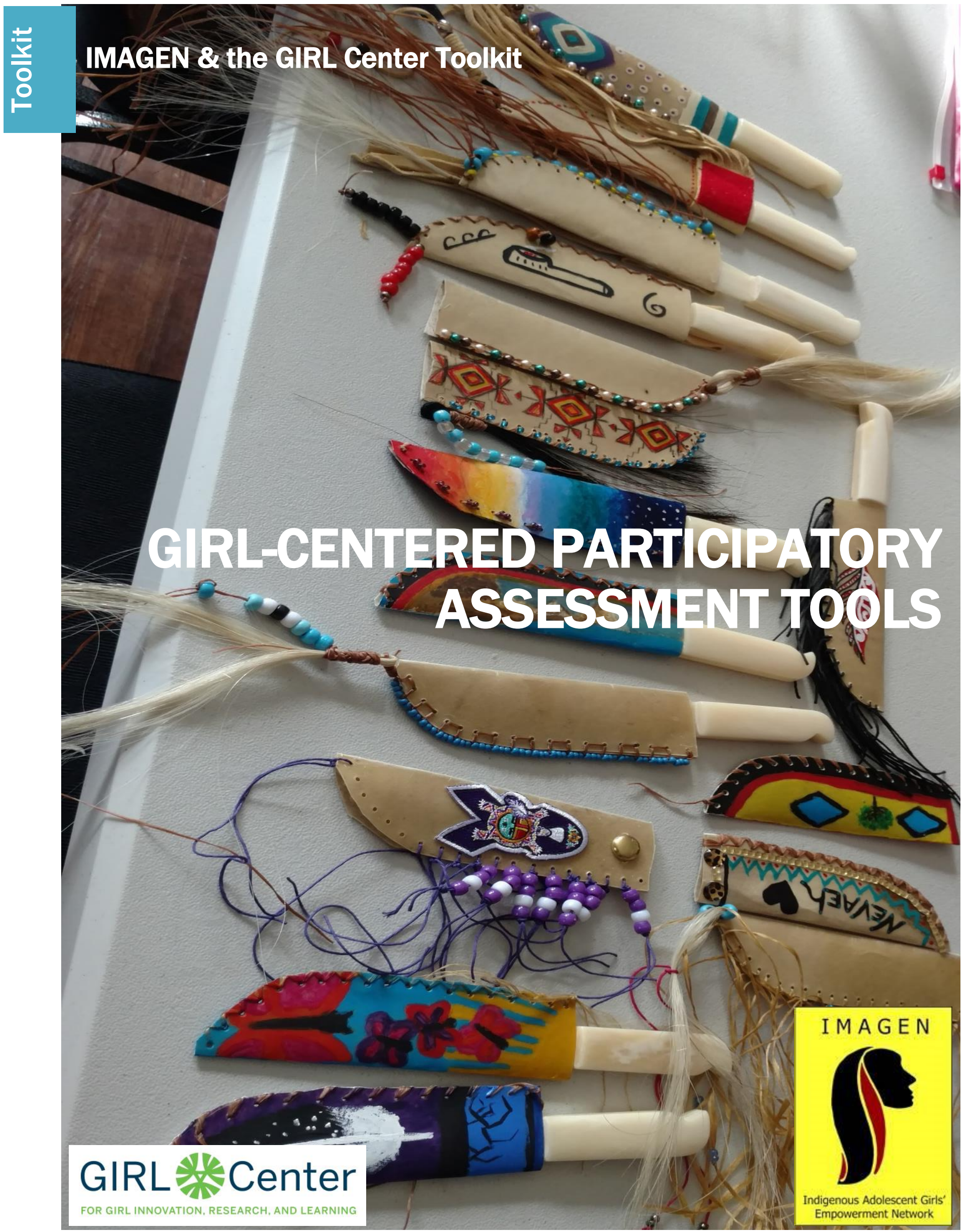




\title{
Girl-Centered Participatory Assessment Tools
}

\author{
IMAGEN \\ New York, New York USA \\ GIRL Center for Innovation, Research \& Learning \\ New York, New York USA
}


The Indigenous Adolescent Girls' Empowerment Network (IMAGEN) brings together Native American-serving organizations to build on Native girls' innate talents and address the multiple challenges they face.

The Girl Innovation, Research, and Learning (GIRL) Center is a global research center that generates, synthesizes, and translates evidence to transform the lives of adolescent girls. Through rigorous research about what works - and what doesn't we can better direct limited resources to support evidence-based solutions that improve girls' lives.

Suggested citation:

Kelly K. Hallman. 2019. "Girl-Centered Participatory Assessment Tools." New York: IMAGEN, GIRL Center. 


\section{Table of Contents}

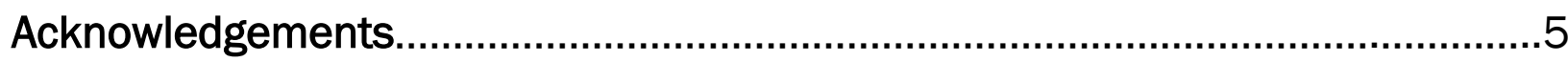

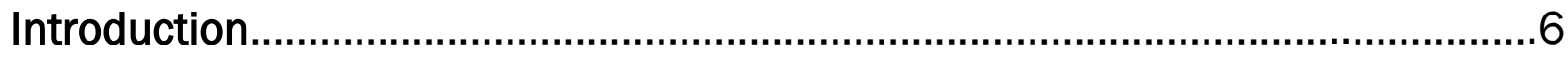

Chapter 1: Community Mapping Exercise...........................................................

Chapter 2: Venn Diagrams of Institutional Access........................................13

Chapter 3: Social Capital Game.................................................................18

Chapter 4: Ascertaining Sexual Relationship Types (ASERTTM) Tool.................24 


\section{Acknowledgements}

Dr. Kelly Hallman designed this toolkit based on research undertaken in Tanzania and South Africa.

For use in other communities, the tools should first be reviewed by local stakeholders and adapted accordingly.

Mr. Adam Weiner and Ms. Sophie Soares helped with compilation and copyediting.

Multiple stakeholders participated in trainings and helped hone the tools for use with girls. They are deeply thanked for their time and energy: Dr. Alison Jenkins, Dr. Fatma Mrisho, Ms. Neema Matee, Mr. Phillipo Paul, Mr. Ilan Cerna-Turoff, Mr. Omari Abungaand, and Ms. Esther Mukasaare. Restless Development staff is gratefully acknowledged for arranging the details and logistics for the trainings.

UNICEF is acknowledged for supporting the original work that laid the basis for the toolkit. 


\section{Introduction}

Even in societies where female movement is not believed to be culturally restricted, research has shown that gender role expectations at the age of puberty limit girls' daily activities and physical movement about the community ${ }^{1}{ }^{2}$. With decreasing ability to move freely, girls' opportunities to form strong social networks, pursue education, participate in income-generating activities, and gain other skills also decline, rendering them more vulnerable to non-consensual sexual encounters, HIV/AIDS, pregnancy, and other unfavorable health and socio-economic outcomes. Limited spatial access by adolescent girls is not widely recognized, and thus, educational, economic, socio-cultural, and legal support mechanisms are not in place to counteract the constraints they newly face with the onset of puberty.

This toolkit is designed to help programs precisely identify the nature and degree of girls' "shrinking worlds" at puberty, and to aid them in devising strategies for offsetting the adverse effects of these restrictions on girls. By "quantifying" the information from each participatory exercise into a speciallydesigned recording grid for that tool, the information can easily be conveyed to decision-makers and others who were not part of the group exercise.

By identifying girl-specific structural barriers and access, programmers can foster extant linkages and trust with local service providers and spaces deemed safe, while also identifying local access points that girls must utilize but that need to be made safer through actions and reforms by local government. Girls' individual and collective agency can be built by improving understanding within local communities of cultivating an environment that is both protective of, yet providing safe freedom of movement to, them.

Experience has shown that to reach adolescent girls effectively, we must develop interventions that create safe spaces that belong to girls ${ }^{3}$, while also safely allowing them to traverse the public domain. This toolkit can help you do that by utilizing the insights and direct participation of adolescent girls to formulate successful programming strategies. The goal is to safely expand girls' access to local services, resources and opportunities.

\section{How to Use this Toolkit}

The chapters in this toolkit provide guidance to facilitators to apply each tool. Facilitators should familiarize themselves with each tool's objectives, supporting materials, and step-by-step procedures. Enclosed in each chapter are also notes for observers, individuals who can document the strengths and weaknesses of the tool's real-life application.

\footnotetext{
${ }^{1}$ Hallman, K., Kenworthy, N., Diers, J., Swan, N., Devnarain, B. (2014). "The Shrinking World of Girls at Puberty: Violence and Gender-Divergent Access to the Public Sphere among Adolescents in South Africa," Global Public Health: An International Journal for Research, Policy and Practice, 2014 Oct 10:1-17. http://dx.doi.org/10.1080/17441692.2014.964746

2 Mensch B, Bruce J, Greene M. (1998). The uncharted passage: girls' adolescence in the developing world. New York: Population Council. http://www.popcouncil.org/uploads/pdfs/passage/passage.pdf

3 Bruce, J., \& Hallman, K. (2008). Reaching the girls left behind. Gender \& Development, 16(2), 227-245.
} 
This toolkit was tested in various sites in Tanzania with pre-existing groups of out-of-school girls aged 1519 and 20-24 years who were part of a girls' empowerment program ${ }^{4,5}$.

Strong recommendations for using the toolkit include:

1. A safe and private space is absolutely required. The original application of the toolkit was with 15-24-year-old girls and young women in Tanzania, and part of a research project that was cleared with the IRBs of the Tanzania National Institute for Medical Research (NIMR) and the Population Council. If used by advocates or program staff, ensuring confidentiality of responses and safety of participants is paramount. Ideally, psychosocial support should be identified before the exercise and available to any girls who may experience feelings or memories associated with past traumatic experiences.

2. It is key to work with pre-existing groups of girls who trust each other and feel comfortable expressing their ideas to one another.

3. All girls in the group exercises should be within a locally defined and meaningful "segment" of girls (e.g., girls aged 15-18 years). For those younger than 25 years, age ranges for participants in focus group sessions should be somewhat narrow and correspond to development stages.

4. One should not ask about any individual girl's experience or behavior; the tools are only effective when "girls like you in this community" are asked about. This provides girls with confidentiality, anonymity and safety in responding to the questions.

5. The sequence of the four tools is important. It starts with one that is broad and general and progresses consecutively to more personal and intimate levels of information. It is therefore best to use the tools (a) in the order given here and (b) with the same group of girls doing all four. Trust is built with each successive tool and this allows girls to more comfortably provide information as they move through the set of tools.

6. For each tool, a session that includes a demonstration, an application, followed by feedback, requires approximately 3 hours. Using all four tools with a group is a two-day endeavor (two tools per day). Please allow this amount of time. Do not rush the girls. Provide them with food and beverages between each session.

7. The fourth exercise (ASERT ${ }^{\mathrm{TM}}$ ) may not be appropriate for girls younger than 14 years of age.

This toolkit is intended for program staff interested in working with segments of adolescent girls aged 1014, 15-19 and/or 20-24 years of age. My hope is that you will apply the tools and use the results to inform your girl program priorities based on the realities of local segments of girls and not based on anyone's assumptions about them.

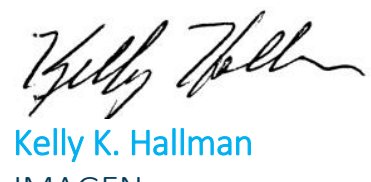

IMAGEN

GIRL Center

${ }^{4}$ Kelly Hallman, Sara Peracca, Alison Jenkins, Neema Matee, Phillipo Paul and Fatma Mrisho (under review). Girls' Participatory Action Quantified Tools (G-PAQT) Reveal Girl-Specific Structural Access and Barriers. New York: Population Council.

5 Kelly Hallman, Sara Peracca, Alison Jenkins, Neema Matee, Phillipo Paul, Ilan Cerna-Turoff, Fatma Mrisho, and Judith Bruce (under review). The ASERT method reveals a transactional - socio-emotional continuum of 13 sexual partner types among adolescent girls and young women in Tanzania. New York: Population Council. 


\title{
Chapter 1
}

\section{COMMUNITY MAPPING EXERCISE Facilitator Guidance Sheet}

\author{
INTRODUCTION \\ Community maps are important tools to help you understand where the girls with whom you work can \\ and cannot go in the community. ${ }^{6}, 7$ This tool helps identify key community resources as well as areas that \\ may be considered problematic or unsafe. By conducting this activity with groups of girls defined by \\ common characteristics (for example by age groups 10-14, 15-19 and 20-24 years), you can compare \\ their different perceptions of the community and the differences in their access to areas and services.
}

After creating each map, you will lead a discussion about the places in the community where the girls can and cannot go and record the reasons why. By exploring these, you will gain a greater understanding of the daily experiences of the girls in the group and identify potential obstacles to their staying safe, participating in the group, and accessing services.

Please encourage all girls to participate. Let them know that this is a collective exercise designed to help them communicate their experiences. Some girls will interpret certain locations differently than others; this is perfectly acceptable and it is your job to help the girls find an acceptable solution. Some girls will feel a certain location is safe while others feel it is unsafe; this is also okay.

\section{OBJECTIVES}

1. To identify girls' perceptions of community resources and important structures, organizations or institutions.

2. To highlight the areas of frequent, occasional, rare and no access by the girls, as well as areas that may be unsafe or are perceived as unsafe.

3. To identify reasons why some places are accessible while others are not.

\section{MATERIALS}

- Large sheets of paper such as flip chart paper or butcher paper (one per map)

- Writing tools (several colored markers, crayons, or pencils)

- Large smooth table or floor space

\section{IMPORTANT CONSIDERATIONS}

1. Think about how the group views their community

a. Do they all live within the same small village?

\footnotetext{
${ }^{6}$ Community mapping originated with the participatory rural appraisal (PRA) research of Robert Chambers. See: Chambers, R. (1992). "Rural appraisal: Rapid, relaxed and participatory." Institute for Development Studies Discussion Paper No. 311; Chambers, R. (1994). "The origins and practice of participatory rural appraisal." World Development 22(7): 953-969; Chambers, R. (1997). Whose Reality Counts?: Putting the First Last. Intermediate Technology Publications Ltd (ITP).

7 Other examples of mapping methods applied with adolescent girl groups include: Brady, M. (2003). "Safe spaces for adolescent girls." Background document to Adolescent and Youth Sexual and Reproductive Health: Charting Directions for a Second Generation of Programming.. New York: UNFPA and Population Council, pp. 155-176; Austrian, K., \& Ghati, D. (2010). Girl centered program design: a toolkit to develop strengthen \& expand adolescent girls programs; Hallman, K., et al. (2014). (op cite).
} 
b. Do they all live within one neighborhood of a larger town or city?

c. If they come from different areas, then have them map the area surrounding where their girl group meets

2. If the girls in your group vary by age, you will need to break them into separate groups (10-14, 15-19 and 20-24 years of age)

a. Grouping by age is important if you want to see how perspectives on the community differ by age and will be important if you have a wide age range of girls in the group

3. Often one person will dominate the group, so consider assisting them with the process to encourage all of the girls to participate. If there is more than one group of girls creating maps at the same time, make sure you can work with all the groups or have someone that you and the girls trust there to assist you.

\section{PROCEDURE}

Step 1: Dividing the girls into smaller groups and preparing the map

Divide girls into small groups of 5-8 girls in each group according to age. Explain that they will be drawing a map of their community and provide some background on the purpose of the exercise, focusing on the fact that they will be using the map to identify places where they do and do not go and those that are safe and unsafe (see the Introduction, pg. 6). Instruct them to begin by thinking of a central reference point, such as a main road, marketplace, or the group meeting place. If the girls are having a hard time deciding on a central reference point, have them brainstorm a number of possibilities and write them on the flip chart paper.

\section{Step 2: Drawing the map}

Ask each small group to start at the central reference point and then begin drawing all of the major places they know (schools, religious buildings, markets, bars, shops, clinics, bus stops, railroad tracks, roads, recreational areas, police stations).

Step 3: Identifying spaces in the community where girls visit In order to understand how the girls move about the community, ask the girls to place a heart next to places where they spends the most time, a triangle next to places they spends some time, a square next to places they rarely go, and an X next to places they never go. To assist the girls, please draw the shapes and what they represent on the chalkboard or on flip chart paper so it is visible during the mapping exercise.

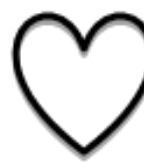

Heart: Spend most time at this place

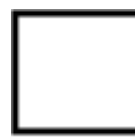

Square: Rarely go here

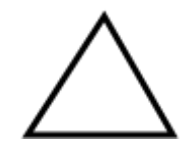

Triangle: Spend some time at this place

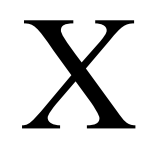

$X$ : Do not go here

Step 4: Exploring unsafe places

In order to assist the girls in identifying and discussing the places in their communities that may be unsafe, ask the girls to draw a circle around the places they feel are unsafe. Then instruct them to rank 
each of the unsafe spaces by writing a number 1 through 5 next to each circle where 1 is unsafe and 5 is extremely unsafe. If a space is safe they can leave it marked with only the shapes from Step 3.

Step 5: Exploring the spaces where girls go and do not go

Display the finished maps by taping them to the wall, chalkboard, or some other visible space. Have a representative from each group present their map and discuss all of the places they included in it and why.

Step 6: Recreate the "Facilitator's Recording of Map Features Grid"

While the girls are finishing up the maps, recreate the table from the "Facilitator's Recording of Map Features Grid" on a large sheet of paper and display it on the wall where the girls can see it. As the girls present the places they go and do not go, record them on the table, checking off the appropriate box and noting the reasons for going or not going to the place.

Step 7: Discussion

Using the completed "Facilitator's Recording of Map Features Grid", initiate a discussion about the places in the community where girls cannot go and why they cannot go there. Explore the reasons that they do and do not go to different places: Is it unsafe? Do their parents or guardians forbid them from going there? Is it too far from home? Do they have to go through an unsafe area to get there? For each location on the map, ask the girls for the reason why they do or do not go there and record this in Facilitator's Recording of Map Features chart. For each place on the map, be sure to do the following:

1. Write the name of the place

2. Check the box to identify how often they go there

3. Write the safety ranking number (1-5) for those places that were circled as unsafe and a 0 for those places considered safe

4. Note the reason for rating each place

Step 8: Ensure the all the Community Map Features are recorded When the exercise is finished be sure that the "Facilitator's Recording of Map Features Grid" you created on the wall is completely filled out. If there is any missing information please ask the participants to assist you in filling it out before they leave. 
FACILITATOR'S RECORDING OF MAP FEATURES GRID

Directions: List each place shown on the map, how often girls go to that place, why they do or do not go to that place, and why they consider it safe or unsafe.

Country: Region/State: Community:

Facilitator name: Date: (dd)/ $(\mathrm{mm}) /$ (yy)

Age of girls in this exercise: to (years)

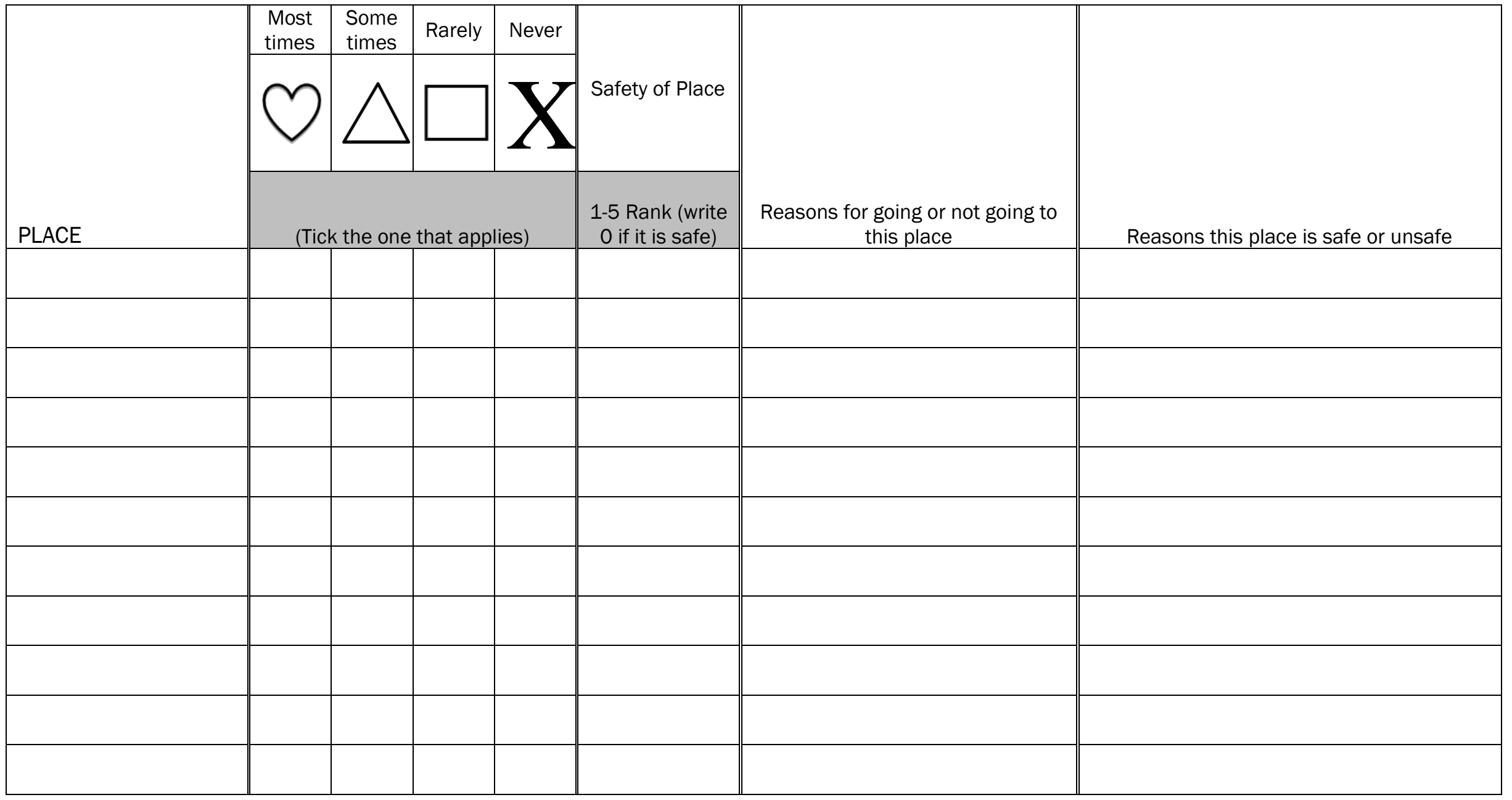




\section{FOR USE BY OBSERVER \\ Structured Observation Checklist: Community Mapping}

Instructions for Observer: Below is an assessment tool to determine the interaction of the facilitator during the community mapping exercise. Place a tick mark in the appropriate box for "Degree of Completion" for each of the Key Elements.

IMPORTANT: PLEASE TAKE A PHOTO OF EACH COMPLETED MAP AND INCLUDE IT WITH YOUR REPORT.

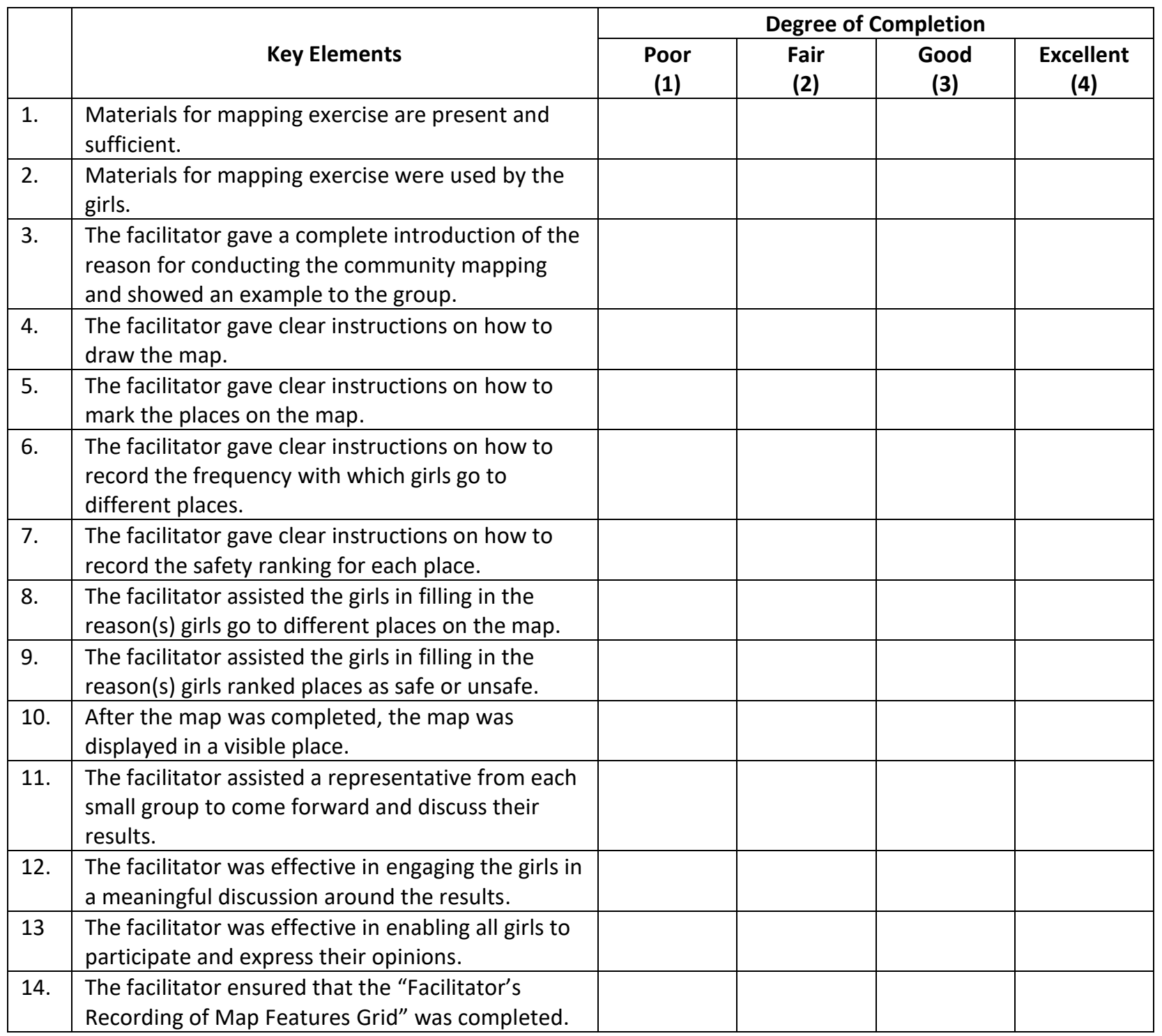




\title{
Chapter 2
}

\section{VENN DIAGRAMS OF INSTITUTIONAL ACCESS Facilitator Guidance Sheet}

\begin{abstract}
INTRODUCTION
Venn Diagrams are an important tool for identifying and classifying data: in this case girls' perceptions of the roles of different organizations and groups within the community ${ }^{8}$. You will use the Venn Diagram to identify the local organizations and institutions that operate in the community - such as schools; the church, mosque or other religious institution; health clinics; nonprofit organizations or community-based organizations; local government; community groups; youth groups; marketplace; and local businesses, among others - and their relative importance in the lives of girls, as reported by your group.
\end{abstract}

You will explore girls' perceptions of the influence of organizations in girls' lives, girls' trust in them, and access to them. By exploring these relationships, you will gain a greater understanding of the daily experiences of local segments of girls. This may include things that affect how and when they come to this group, spend time with friends, engage in recreational activities, access services and information, and the type and quality of the information they receive, among other things.

Please encourage all girls to participate. Let them know that this is a collective exercise designed to help them communicate their experiences. Some girls will interpret certain organizations differently than others; this is perfectly acceptable and it is your job to help the girls discuss and find the best way to represent this on the Venn Diagram.

\section{OBJECTIVES}

1. To identify the different organizations and actors within the community as perceived by girls.

2. To explore girls' views of the influence of organizations on girls' lives; girls' trust in organizations; and girls' linkages (access) to organizations and services.

\section{MATERIALS}

- Large sheets of paper such as flip chart paper or butcher paper - one per group plus 2-3 extra for your use for writing on as a demonstration

- Colored markers (at least two per group)

\section{IMPORTANT CONSIDERATIONS}

1. Divide girls into small groups of 5-8 participants by age category (10-14, 15-19, and 20-24 years).

2. Often one person will dominate a discussion so consider assisting each group with the process to encourage all of the girls to participate. Make sure you can work with all the groups or have someone you and the girls trust there to assist you.

\footnotetext{
8 This tool was inspired by the work of (a) Conradin, K., Kropac, M., Spuhler, D. (Eds.). (2010). The SSWM Toolbox. Basel: SEECON International GMBH. URL: http://www.sswm.info. Accessed: 17 June 2015, and that of (b) Fraser, E., Thirkell, A., McKay. A. (2003). Tapping into Existing Social Capital: Rich Networks, Poor Connections. Social Development Direct, Sinani, and Institute for Participatory Interaction in Development. London, UK. 


\section{PROCEDURE}

Step 1: Dividing the girls into smaller groups

Divide girls into small groups of 5-8 participants by age category (10-14, 15-19, and 20-24 years). Explain that they will be creating something called a Venn Diagram and provide some background on their use (see the Introduction above).

\section{Step 2: Identifying the organizations and institutions}

Begin by asking the girls to brainstorm all of the different organizations and actors that are either based in the community or operate there in some way. Ask one girl from the group to list these on a large sheet of paper that is visible to the entire group. Some examples of organizations and actors may be: schools, churches, mosques, local government bodies, police, recreational facilities, criminals, drunks, other informal groups, farmer cooperatives, businesses, health clinics, parent or youth groups, and nonprofit organizations.

\section{Step 3: Exploring influence}

Ask the girls to look at the list of organizations and institutions they made, and think about how each affects local girls like them. It is possible that some groups have no influence at all on girls. Ask girls to signify the level of influence of each organization on girls like them by using a small, medium or large circle to the right of the organization name.

\begin{tabular}{|l|c|l|l|}
\hline Organization & Influence on girls & Girls' trust in & Girls' linkage to \\
\hline Organization 1 & 0 & & \\
\hline Organization 2 & 0 & & \\
\hline Organization 3 & 0 & & \\
\hline Organization 4 & 0 & & \\
\hline
\end{tabular}

Step 4: Exploring trust and linkages

Ask the girls to think about those organizations and institutions that they trust the most. Instruct the girls to put a " + " symbol on the circles of those organizations and institutions that signifies how much they trust the organization or institution. They can place a maximum of 2 " + " symbols depending on the level of trust they have.

1. NT signifies No Trust

2. " " " signifies Some Trust

3. " ++ " signifies A Lot of Trust

Ask the girls to think about those organizations and institutions that they feel they have linkages with or access to. Instruct the girls use the " $\infty$ " symbol to signify how much they trust the organization or institution. They can place a maximum of two " $\infty$ " symbols depending on the level of trust they have.

1. NL signifies No Linkage

2. " $\infty$ " signifies Some Linkage

3. " $\infty \infty$ " signifies A Lot of Linkage

Step 5: Recreate the "Facilitator's Recording of Venn Diagram Features Grid" While the girls are finishing up the Venn Diagrams, recreate the table from the "Facilitator's Recording of Venn Diagram Features Grid" (see below) on a large sheet of paper and display it up on the wall or another place where the girls can see it. As the girls present the organizations and institutions, record 
them on the table, during the discussion period check off the appropriate sized circle and the Trust and Link boxes.

Step 6: Discussion

Ask a representative from each group to present its Venn Diagram. Using the "Facilitator's Recording of Venn Diagram Features Grid" below, initiate a discussion to get a clearer understanding of the relationships represented on the Venn Diagram. For each circle drawn, ask the girls for the reason they rated it as they did and record this in "Facilitator's Recording of Venn Diagram Features Grid". Be sure to do the following:

1. Write the name of the place

2. Check the box to mark it as a large, medium or small circle

3. Check the box that corresponds to how trusted it is by the girls.
a. "NT" signifies No Trust
b. " + " signifies Some Trust
c. " ++ " signifies A Lot of Trust

3. Check the box that corresponds to what extent girls have a link to it.
a. "NL" signifies "No" Links
b. " $\infty$ " signifies "Some" Links
c. " $\infty \infty$ " signifies "A Lot" of Links

4. Note the reason for trust and link ratings of each group in the last column of the Grid

Step 7: Ensure all the Venn Diagram features are recorded

When the exercise is finished and BEFORE the girls have left be sure that the "Recording of Venn Diagram Features Grid" you created is completely filled out. Every organization on the Venn Diagram should be listed, along with its circle size, Trust and Link rating. If there is any missing information please ask the participants to assist you in filling it out before they leave. 


\section{FACILITATOR'S RECORDING OF VENN DIAGRAM FEATURES GRID}

Directions: List each organization shown on the diagram, record the size of the circle, how it was rated regarding Trust and Link.

Country: Region/State: Community:

Facilitator name: Date: (dd)/ $(\mathrm{mm}) /$ (yy)

Age of girls in this exercise: to (years)

\begin{tabular}{|c|c|c|c|c|c|c|c|c|c|c|}
\hline \multirow[b]{2}{*}{$\begin{array}{c}\text { GROUP / } \\
\text { ORGANIZATION }\end{array}$} & $\begin{array}{l}\text { Large } \\
\text { Circle }\end{array}$ & $\begin{array}{l}\text { Medium } \\
\text { circle }\end{array}$ & $\begin{array}{l}\text { Small } \\
\text { circle }\end{array}$ & \multicolumn{3}{|c|}{$\begin{array}{c}\text { Trust } \\
\text { (Tick the one that applies } \\
\text { based on the + symbols) }\end{array}$} & \multicolumn{3}{|c|}{$\begin{array}{c}\text { Link } \\
\text { (Tick the one that applies } \\
\text { based on the } \infty \text { symbols) }\end{array}$} & \multirow{2}{*}{$\begin{array}{l}\text { Explain the reasons for (a) the size } \\
\text { of the circle/square, (b) the trust } \\
\text { rating, and (c) why link or no link }\end{array}$} \\
\hline & \multicolumn{3}{|c|}{ (Tick the one that applies) } & $\begin{array}{c}\text { None } \\
\text { (NT) }\end{array}$ & $\begin{array}{c}\text { Some } \\
(+)\end{array}$ & $\begin{array}{l}\text { A Lot } \\
(++)\end{array}$ & $\begin{array}{l}\text { None } \\
(\mathrm{NL})\end{array}$ & $\begin{array}{c}\text { Some } \\
(\infty)\end{array}$ & $\begin{array}{c}\text { A Lot } \\
(\infty \infty))\end{array}$ & \\
\hline & & & & & & & & & & \\
\hline & & & & & & & & & & \\
\hline & & & & & & & & & & \\
\hline & & & & & & & & & & \\
\hline & & & & & & & & & & \\
\hline & & & & & & & & & & \\
\hline & & & & & & & & & & \\
\hline & & & & & & & & & & \\
\hline
\end{tabular}




\section{FOR USE BY OBSERVER Structured Observation Checklist: Venn Diagram}

Instructions for Observer: Below is an assessment tool to determine the interaction of the facilitator during the Venn Diagram exercise. Place a check mark in the appropriate box for "Degree of Completion" for each of the Key Elements.

IMPORTANT: PLEASE TAKE A PHOTO OF EACH COMPLETED VENN DIAGRAM AND INCLUDE IT WITH YOUR REPORT.

\begin{tabular}{|c|c|c|c|c|c|}
\hline & \multirow[b]{2}{*}{ Key Elements } & \multicolumn{4}{|c|}{ Degree of Completion } \\
\hline & & $\begin{array}{l}\text { Poor } \\
\text { (1) }\end{array}$ & $\begin{array}{c}\text { Fair } \\
(2)\end{array}$ & $\begin{array}{c}\text { Good } \\
\text { (3) }\end{array}$ & $\begin{array}{l}\text { Excellent } \\
\text { (4) }\end{array}$ \\
\hline 1. & $\begin{array}{l}\text { Materials for the Venn Diagram exercise are present and } \\
\text { sufficient. }\end{array}$ & & & & \\
\hline 2. & $\begin{array}{l}\text { The girls used materials for Venn Diagram exercise during } \\
\text { the creation of the Venn Diagrams. }\end{array}$ & & & & \\
\hline 3. & $\begin{array}{l}\text { The facilitator gave a complete introduction about the } \\
\text { reason for creating the Venn Diagram. }\end{array}$ & & & & \\
\hline 4. & $\begin{array}{l}\text { The facilitator conducted a brainstorming activity to help } \\
\text { the girls identify the organizations and institutions that } \\
\text { exist or operate in the community and wrote down the list } \\
\text { on a large, visible sheet of paper. }\end{array}$ & & & & \\
\hline 5. & $\begin{array}{l}\text { The facilitator explained that large circles represent } \\
\text { greater influence on the girls group, while medium and } \\
\text { small circles represent decreasing influence. }\end{array}$ & & & & \\
\hline 6. & $\begin{array}{l}\text { The facilitator explained that some organizations and } \\
\text { institutions are trusted by girls, while others are not. The } \\
\text { facilitator clearly instructed the girls to use symbols to } \\
\text { signify the level of trust. }\end{array}$ & & & & \\
\hline 7. & $\begin{array}{l}\text { The facilitator explained that girls can access some } \\
\text { organizations and institutions, but not others. The } \\
\text { facilitator clearly instructed the girls to use symbols to } \\
\text { signify the level of linkage girls have. }\end{array}$ & & & & \\
\hline 8. & $\begin{array}{l}\text { The facilitator assisted a representative from each group } \\
\text { to come forward and present their Venn Diagram. }\end{array}$ & & & & \\
\hline 9. & $\begin{array}{l}\text { The facilitator engaged the girls in a meaningful dialogue } \\
\text { about the relationships of the different institutions in the } \\
\text { community and the trust and access girls have. The } \\
\text { facilitator recorded these in the last column of the } \\
\text { "Facilitator's Recording of Venn Diagram Features Grid". }\end{array}$ & & & & \\
\hline 10. & $\begin{array}{l}\text { The facilitator was effective in enabling all girls to } \\
\text { participate and express their opinions. }\end{array}$ & & & & \\
\hline 11. & $\begin{array}{l}\text { The facilitator made sure the "Facilitator's Recording of } \\
\text { Venn Diagram Features Grid" was complete. }\end{array}$ & & & & \\
\hline
\end{tabular}




\section{Chapter 3}

\section{SOCIAL CAPITAL GAME \\ Facilitator Guidance Sheet}

\section{INTRODUCTION}

Social Capital is based on the nature of relationships, or social networks, and the trust and reciprocity (or inclination towards helping each other) that arise from these relationships. It focuses on the social networks that exist between us (who knows whom) and the character of those networks, the strength of the relationships within those networks, and the extent to which those networks foster trust. ${ }^{9}$

One of the most important factors related to social capital are trust, power, and linkages. Trust exists in different forms: For example, the trust you have for your family and friends is different than the trust you have in the owner of a local store who you know is honest and does not steal from her customers. In small communities, the reputation of trustworthy or untrustworthy individuals is often well known since this information travels from person-to-person through communications networks, friendships, and other relationships. When trust exists, people are willing to do things for one another even for no pay or compensation. The power of one person over another also influences the nature of their relationship. Powerful individuals may have more influence over the girls in your group. The direct access, or linkage, that the girls in your group have with these people also affects the strength of their connections to the persons. When a person does not have a direct linkage with a figure in the community, she will still either trust or not trust that figure depending on his or her reputation and relationships with others in the community.

The Social Capital Game ${ }^{10}$ is a fun, interactive way to examine girls' connections with key figures in their community. It gives the girls the opportunity to identify key figures in the community or those that operate in the community and have an influence on their lives, such as political leaders, teachers, community leaders, and parents. The Social Capital Game helps the girls examine who of these key figures is trusted, who is powerful, and with whom they have a link. After completing the Social Capital Game, you will lead a discussion with the girls on the nature of their relationships with these key individuals and how their perceptions may be similar or different from one another. By exploring these relationships, you will gain a greater understanding of the daily experiences of the girls in the group and identify some of the ways individuals in their communities can impact them, both directly and indirectly.

Please encourage all girls to participate. Let them know that there are no wrong choices or answers for the Social Capital Game and that this is an exercise designed to help them communicate their experiences within the community. Some girls will have different perceptions than others; this is fine and it is your job to help the girls find the best way to represent their attitudes during the game.

\footnotetext{
${ }^{9}$ Social Capital Building Toolkit Version 1.2 (Thomas Sander/Kathleen Lowney). Saguaro Seminar: Civic Engagement in America, John F. Kennedy School of Government, Harvard University. Accessed online 28-July-14.

${ }^{10}$ This tool is inspired by the work of Fraser, E., Thirkell, A., McKay. A. (2003). Tapping into Existing Social Capital: Rich Networks, Poor Connections. Social Development Direct; Sinani; and Institute for Participatory Interaction in Development. London, UK.
} 


\section{OBJECTIVES}

1. To identify key individuals within the community or those that operate within the community

2. To explore the influence of these key individuals by analyzing issues of trust, power, and connection

\section{MATERIALS}

- Large sheets of paper such as flip chart paper or butcher paper (3-4 for your use for writing on as a demonstration)

- Blank cards or sheets of regular (A4) paper that can be cut into squares (10 total squares will be needed)

- 10 chairs

- Writing tools (several colored markers, crayons or pencils)

- 18 of the same small object e.g. coins, index cards, erasers, etc. These objects will represent trust, power and links during the game. You should have enough to give about 3 of the objects to each participant.

- Tape

\section{IMPORTANT CONSIDERATIONS}

1. Social capital can be a difficult concept to understand. It will be very important for you as the facilitator to ask questions about the girls' social networks and how they trust others within the community. Be sure to discuss how people perceive power and how it can impact us depending on the nature of the relationship we have with the person of power.

2. Often one person will dominate a discussion so consider assisting to encourage all of the girls to participate. Make sure you can work with all the girls or have someone you and the girls trust there to assist you.

\section{PROCEDURE}

Step 1: Introduction to social capital

Begin this game by convening a group of 5-8 girls within the same age range: 10-14, 15-19 or 20-24 years. Next introduce the concept and be sure to include the following ideas:

1. Social capital is based on the nature of relationships or social networks.

2. Trust, power and linkages are key elements to social capital.

3. Inform them that when something we do, such as a community improvement project, builds linkages and trust between people, we are also building social capital because we are expanding our social networks and strengthening them.

Be sure to encourage all girls to participate in the discussion.

\section{Step 2: Identifying key individuals}

Ask the girls in the group: "Who are the key people in this community or who operate in this community?" Choose 10 key individuals and write their titles - such as religious leader, teacher, shopkeeper, mayor, or policeman - on blank cards. Please be sure to use the titles of the key individuals and not their names. Tape each of these cards to an empty chair and place the chairs in a circle (or place the cards in 10 different locations on a table). Recreate the chart seen in the Facilitator's Recording of Social Capital Game Features form on a large sheet of paper and write the titles of the 10 key individuals down the first column. Hang this in a place that is visible to all. 
Step 3: Hand out three of the social capital objects (e.g. coins, index cards, whatever you have chosen) to each participant. Each round, the same object will represent power, link, and trust respectively.

For example, if you have chosen to use coins, each participant should have three coins in their hands. During Step 4, 5, and 6, they will use the same three coins, retrieving them from the chairs after each step is complete.

\section{Step 4: Trust}

1. Discuss with the girls how there are those key individuals that they trust and those that they do not. It is possible that some girls will trust someone while others will not and that this is normal since views vary among people. Instruct the girls to walk around the circle of key individuals and to think about how they may trust these key individuals. Explain that they have 3 objects representing trust and they will give those out to the key individuals they trust by placing them on the seat of the chair. They can give all 3 objects to one individual if they feel they trust him/her very strongly, divide them up among a 2 or 3 of individuals, or not give any out if they do not trust any of the key individuals.

2. When all girls have given out their Trust objects, ask a volunteer to help by counting up the number of Trust objects each key individual has. You will then record these numbers in the Trust column on the large sheet of paper that you prepared to resemble the "Facilitator's Recording of Social Capital Features Grid."

3. Discuss with the girls why some key individuals have more trust than others. What are the factors that lead to trust or no trust? Record (or have the girls record) these reasons on the chart you have made.

\section{Pick up all the objects and divide them among the girls again.}

\section{Step 5: Power}

1. Take a moment to discuss with the girls the idea of power. Have them brainstorm ideas on what it means to have power and what it means to not have any power. Instruct the girls to walk around the circle of key individuals and think about which of them have power. Explain that they have 3 objects representing power and that they will give their objects out to those individuals they think have the most power by placing them on the seat of the chair (or on the table). They can give all 3 objects to one individual if they feel he/she has a great deal of power, divide them up between 2 or 3 individuals, or not give any out if they feel that none of the individuals have power.

2. When all girls have given out their Power objects, ask a volunteer to help by counting the number of Power object each key individual has. You will then record these numbers in the Power columns on the large sheet of paper.

3. Discuss with the girls why they perceive that some key individuals have more power than others. What are the factors that give someone power? Record (or have the girls record) these reasons on the chart you have made.

4. Pick up all the objects and divide them among the girls again.

Step 6: Link

1. Take a moment to discuss with the girls the idea of how they are linked with some people but not with others. Ask them for examples of individuals they are linked with those they are not linked. Ask the girls to walk around the circle of key individuals and think about which of them they may have a link with. Instruct them to give their objects representing links out to those key individuals that they have the 
strongest link with by placing them on the seat of the chair. They can give all 3 objects to one individual, divide them up between 2 or 3 individuals, or not give any out if they feel they are not linked with any of them.

2. When all girls have given out their Link objects ask that a volunteer help count the number of Link objects cards each key individual has. You will then record these numbers in the Link column on the large sheet of paper.

3. Discuss with the girls the nature of the links with the key individuals. Are there any key individuals with whom they would like to build a stronger link? Record (or have the girls record) these reasons on the chart you have made.

4. Pick up all the objects and divide them among the girls again.

Step 7: Discussion

Lead a discussion with the girls about their experiences with this game. Are there any scores that they find surprising? Why are some key individuals more trusted than others? Why are some key individuals more powerful than others? Does being linked or not linked with any of these key individuals have any benefits or cause any difficulties?

Step 8: Recording of Social Capital Game Features

When the game is finished and the girls have left be sure to fill out the "Facilitator's Recording of Social Capital Game Features Grid" on the next page. Write down any other important points or issues related to the key individuals that were raised during the game in the last column. 
FACILITATOR'S RECORDING OF SOCIAL CAPITAL GAME FEATURES GRID

Directions: List each key individual from the Social Capital Game and write the total number of objects they receive for each category. Record the reasons for the count for that individual in the last column.

Country:

Region/State:

Community:

Facilitator name:

Date:

(dd)/

$(\mathrm{mm}) /$

(yy)

Age of girls in this exercise:

to

(years)

\begin{tabular}{|c|c|c|c|c|}
\hline & \multicolumn{3}{|c|}{ NUMBER OF OBJECTS } & \\
\hline KEY INDIVIDUAL & Trust & Power & Link & List reasons for trust, power and link ratings \\
\hline & & & & \\
\hline & & & & \\
\hline & & & & \\
\hline & & & & \\
\hline & & & & \\
\hline & & & & \\
\hline & & & & \\
\hline & & & & \\
\hline & & & & \\
\hline & & & & \\
\hline
\end{tabular}




\section{FOR USE BY OBSERVER \\ Structured Observation Checklist: Social Capital Game}

Instructions for Observer: Below is an assessment tool to determine the effectiveness of the facilitator in leading the Social Capital Game. Place a check mark in the appropriate box for "Degree of Completion" for each of the Key Elements.

IMPORTANT: PLEASE TAKE A PHOTO OF THE COMPLETED GRID AND INCLUDE IT WITH YOUR REPORT.

\begin{tabular}{|c|c|c|c|c|c|}
\hline & \multirow[b]{2}{*}{ Key Elements } & \multicolumn{4}{|c|}{ Degree of Completion } \\
\hline & & $\begin{array}{l}\text { Poor } \\
\text { (1) }\end{array}$ & $\begin{array}{l}\text { Fair } \\
(2)\end{array}$ & $\begin{array}{c}\text { Good } \\
(3)\end{array}$ & $\begin{array}{l}\text { Excellent } \\
\text { (4) }\end{array}$ \\
\hline 1. & Materials for the Social Capital Game are present and sufficient. & & & & \\
\hline 2. & $\begin{array}{l}\text { The facilitator used materials for the Social Capital Game and } \\
\text { followed instructions on how to use them. }\end{array}$ & & & & \\
\hline 3. & $\begin{array}{l}\text { The facilitator gave a complete introduction of the concept of } \\
\text { social capital and covered all of the points listed in Step } 1 \text { of the } \\
\text { Procedure section }\end{array}$ & & & & \\
\hline 4. & $\begin{array}{l}\text { The facilitator assisted the girls in identifying a number of key } \\
\text { individuals in the community and selecting } 10 \text { of them. The } \\
\text { facilitator wrote the descriptions - not the names - of the key } \\
\text { individuals on a sheet of paper and taped each one to a chair, } \\
\text { forming a circle with all of the chairs. }\end{array}$ & & & & \\
\hline 5. & $\begin{array}{l}\text { The facilitator recreated the table from the Facilitator's } \\
\text { Recording of Social Capital Features Grid on a large sheet of } \\
\text { paper and placed it in a visible place. }\end{array}$ & & & & \\
\hline 6. & $\begin{array}{l}\text { The facilitator led a discussion on trust and how that may relate } \\
\text { to the key individuals. She then led the group through the } \\
\text { Trust/No Trust part of the game and successfully tallied all of } \\
\text { the Trust/ No Trust scores. }\end{array}$ & & & & \\
\hline 7. & $\begin{array}{l}\text { The facilitator led a discussion on power and how that may } \\
\text { relate to the key individuals. She then led the group through the } \\
\text { Power/No Power part of the game and successfully tallied all of } \\
\text { the Power/No Power scores. }\end{array}$ & & & & \\
\hline 8. & $\begin{array}{l}\text { The facilitator led a discussion on linkages and how they may } \\
\text { relate to the key individuals. She then led the group through the } \\
\text { Link/No Link part of the game and successfully tallied all of the } \\
\text { Link/No Link scores. }\end{array}$ & & & & \\
\hline 9. & $\begin{array}{l}\text { The facilitator effectively led a discussion at the end of the } \\
\text { game, which strengthened girls' ideas of social capital and the } \\
\text { different components of it. }\end{array}$ & & & & \\
\hline 10. & $\begin{array}{l}\text { The facilitator was effective in enabling all girls to express their } \\
\text { opinions and participate. }\end{array}$ & & & & \\
\hline 11. & $\begin{array}{l}\text { The facilitator completed the "Facilitator's Recording of Social } \\
\text { Capital Game Features Grid". }\end{array}$ & & & & \\
\hline
\end{tabular}




\title{
Chapter 4
}

\section{ASCERTAINING SEXUAL RELATIONSHIP TYPES (ASERT) ${ }^{\mathrm{TM}}$ TOOL (SHORT VERSION) Facilitator Guidance Sheet}

\author{
INTRODUCTION \\ The Ascertaining Sexual Relationship Types (ASERT) ${ }^{\mathrm{TM}}$ Tool is a method for understanding how girls \\ describe and rank different features of people that girls in their community have sex with. Through the \\ ASERT ${ }^{\mathrm{TM}}$ Tool, one creates a visual representation of girls' descriptions about the types of people girls \\ have sex with and the reasons girls have sexual relationships. ${ }^{11}$ This can be a powerful exercise for the \\ girls as it offers them an opportunity to think about and discuss issues related to HIV risk, social status, \\ and economic survival strategies.
}

The ASERT TM Tool exercise you will conduct with the girls group will be focused on their perceptions and attitudes about the reasons girls have sexual relationships with different types of people. You will use this tool to first, identify the types of people that girls have as sexual partners, and second, to list the reasons given for engaging in sexual relationships with each type. The girls will list the most common types of partners and the reasons for having each partner.

\section{RULES FOR APPLYING THE ASERTTM TOOL:}

1. This tool should not be used for girls aged 10-14 years-old. It is only for girls aged 15-19 or 20-24 years.

2. A safe and private space is absolutely required. You must ensure the confidentiality of the responses and comfort and safety of the participants.

3. You must work with pre-existing groups of girls who trust each other and feel comfortable expressing their ideas to one another.

4. You must not ask about any individual girl's experience or behavior; the tool is only effective when you ask about "girls like you in this community". This provides girls with more anonymity and safety. The goal is to explore their opinions about girls like them in the community, not to report on their own individual behaviors or experiences.

5. Tell participants that it is okay to describe the exercise to others outside the group, but ask participants not to share the details of the results with anyone outside the group.

6. Health and psychosocial services should be identified before the exercise, in the case that any girls report experiences of violence or abuse.

After completing the ASERT Tool, you will lead a discussion with the girls on the reasons for ranking different partners. By exploring these issues, you will gain a greater understanding of the experiences of local segments of girls.

\footnotetext{
11 This tool was inspired by the work of Shah, M. K., Kambou, S. D., \& Monahan, B. 1999. Embracing participation in development: worldwide experience from CAREs Reproductive Health Programs with a step-by-step field guide to participatory tools and techniques. Wisdom from the field. 
Please encourage all girls to participate. Let them know that there are no right or wrong answers for the ASERT $^{\mathrm{TM}}$ Tool and that this is an exercise designed to help them communicate their views. Some girls will express their responses differently than others; this is perfectly acceptable and it is your job to help the girls find the best way to represent their beliefs on the ASERT Tool sheet.

\section{OBJECTIVES}

1. To identify the different types of sexual partners girls have

2. To identify the different reasons why girls have sexual relationships with each partner type

\section{MATERIALS}

- $\quad$ Large sheets of paper such as flip chart paper or butcher paper (at least one per group plus 3-4 more for you to use for giving examples)

- Additional regular (A4) size sheets of paper (3-4 sheets per group)

- Writing tools (several colored markers, crayons or pencils)

- Scissors

- Large smooth table or floor space

- Tape or glue

\section{IMPORTANT CONSIDERATIONS}

The ASERT ${ }^{T M}$ Tool is focused on a very sensitive topic that may be very challenging for some girls who may not want to express their thoughts on the subject. PLEASE EMPHASIZE THAT THE EXERCISE IS NOT ABOUT EACH GIRL'S INDIVIDUAL EXPERIENCE, NOR IS IT ASKING THEM TO NAME OR DISCUSS PARTICULAR INDIVIDUALS. THE QUESTIONS PERTAIN TO THE AVERAGE GIRL LIKE HER IN HER COMMUNITY, NOT TO HER. YOU MUST MAKE SURE THIS IS CLEAR FOR ALL GIRLS. This exercise is about girls in the community in general. It is possible that girls of different ages will have different views on the topic. Because of this, it is important to divide the girls into groups according to age. You should divide the girls in groups of 5-8 participants with all girls being in a single age category of either 15-19 or 20-24 years, but not both.

Often one person will dominate a discussion so consider assisting each group with the process to encourage all of the girls to participate. Make sure you can work with all the groups or have someone you and the girls trust there to assist you.

\section{PROCEDURE}

Step 1: Dividing the girls into small groups

Divide girls into small groups of 5-8 participants, making sure to divide them by age (15-19 or 20-24 years). Explain that each small group will be conducting something called the ASERT ${ }^{\mathrm{TM}}$ Tool and provide some background on its purpose (see the Introduction above).

Step 2: Identifying the types of people that are sexual partners for girls

Begin by asking the girls to think about all of the different types of people that girls like them have sex with. Remind them that you are not asking about their own sexual experiences, only about those of girls in the community who are similar to them. You can provide them with some examples, such as: neighbor; classmate; teacher; older married man; uncle; police officer; stranger; family friend; bartender; etc. Please instruct them not to use any names of people in the community. Ask them to list each one of the persons they come up with along the top of the sheet of paper as displayed below. The girls can name as many types of people as they wish. Use extra sheets of paper to make room for additional columns to list these. 


\begin{tabular}{|l|l|l|l|}
\hline Married man & Teacher & Boyfriend & Neighbor \\
& & & \\
\hline
\end{tabular}

Step 3: Identifying the reasons girls have sexual relationships with each partner type Ask the girls to think about each type of sexual partner they identified. For each partner type listed, they should list all of the different reasons that girls like them in their community engage in sexual relationships with that type. You can give them examples such as: my parents like him; he lives close by; he shows me love; he gives me gifts; he has a car to take me places; he has a phone I can use; he pressures me in non-physical ways; he will do favors for me; he helps my family; etc.

Step 4: Ranking the reasons girls have sex with each type of partner

Once the girls have gone through each partner type and listed all of the reasons girls have sexual relationships with that type, instruct them to rank order the reasons given within each type so the most important one is listed first. Each successive reason should be the next most important, with the least important reason last. They should number these reasons 1, 2, 3, 4, etc. In the end, the larger sheet will look something like this:

\begin{tabular}{|l|l|l|l|}
\hline Married man & Boyfriend & Neighbor & Uncle \\
\hline 1. He gives her money & 1. She loves him & $\begin{array}{l}\text { 1. He buys her small } \\
\text { things }\end{array}$ & $\begin{array}{l}\text { 1. Her physically forces } \\
\text { her }\end{array}$ \\
\hline $\begin{array}{l}\text { 2. He does not } \\
\text { interfere with her life }\end{array}$ & $\begin{array}{l}\text { 2. She can make plans } \\
\text { with him }\end{array}$ & $\begin{array}{l}\text { 2. He threatens to ruin } \\
\text { her reputation if she } \\
\text { says no }\end{array}$ & $\begin{array}{l}\text { 2. She does not want to } \\
\text { report his acts because } \\
\text { he is family }\end{array}$ \\
\hline 3 He is not jealous & 3. Common interests & 3. He is always around & $\begin{array}{l}\text { 3. She fears her father } \\
\text { will blame her }\end{array}$ \\
\hline
\end{tabular}

Step 5: Recreate the Facilitator's Recording of ASERT ${ }^{\mathrm{TM}}$ Exercise Features table

While the girls are doing the exercise, recreate the table from the "Facilitator's Recording of ASERT ${ }^{\mathrm{TM}}$ Features Grid" on a large sheet of paper and display it where the girls can see it. As the girls discuss the different sexual partner types, record them on the table, listing the partners in the first column, and the reasons for the sexual relationships by order of importance across the row. Note any important points the girls mention about the different partners and write them in the last column.

Step 6: Discussion

Ask a representative from each group to present the results from their ASERT ${ }^{\mathrm{TM}}$ exercise. After they complete the presentation, ask if anyone has any questions. Discussion will provide a clearer understanding of the relationships represented in the ASERT ${ }^{\mathrm{TM}}$ Grid. Record any further information in the "Notes" column of the Grid on the next page. 


\section{FACILITATOR'S RECORDING OF ASERTTM FEATURES GRID}

Directions: List each person type noted in the ASERT ${ }^{\mathrm{TM}}$ Tool exercise. Record the reasons girls have sex with this person type and write down any other important notes about that person.

Country:

Region/State:

Community:

Facilitator name:

Date:

(dd)/

$(\mathrm{mm}) /$

(yy)

Age of girls in this exercise:

to

(years)

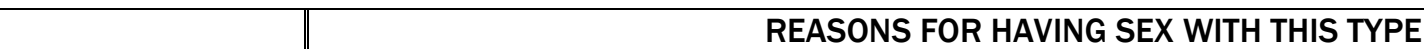

\begin{tabular}{|l|l|l|l|l|l|l|}
\hline \multirow{2}{*}{ PERSON TYPE } & Most important & $\begin{array}{c}\text { Second most } \\
\text { important }\end{array}$ & $\begin{array}{c}\text { Third most } \\
\text { important }\end{array}$ & $\begin{array}{c}\text { Fourth most } \\
\text { important }\end{array}$ & $\begin{array}{c}\text { Fifth most } \\
\text { important }\end{array}$ & $\begin{array}{c}\text { NOTES ABOUT THIS } \\
\text { PERSON TYPE }\end{array}$ \\
\hline & & & & & & \\
\hline & & & & & & \\
\hline & & & & & & \\
\hline & & & & & & \\
\hline & & & & & & \\
\hline & & & & & & \\
\hline & & & & & & \\
\hline & & & & & & \\
\hline & & & & & & \\
\hline
\end{tabular}




\section{FOR USE BY OBSERVER \\ Structured Observation Checklist: ASERT ${ }^{\mathrm{TM}}$ TOOL EXERCISE}

Instructions for Observer: Below is an assessment tool to record how the facilitator conducted the ASERT Tool. Place a check mark in the appropriate box for "Degree of Completion" for each of the Key Elements. IMPORTANT: PLEASE TAKE A PHOTO OF EACH COMPLETED ASERT GRID AND INCLUDE IT WITH YOUR REPORT.

\begin{tabular}{|c|c|c|c|c|c|}
\hline & \multirow[b]{2}{*}{ Key Elements } & \multicolumn{4}{|c|}{ Degree of Completion } \\
\hline & & $\begin{array}{l}\text { Poor } \\
\text { (1) }\end{array}$ & $\begin{array}{l}\text { Fair } \\
\text { (2) }\end{array}$ & $\begin{array}{c}\text { Good } \\
(3)\end{array}$ & $\begin{array}{l}\text { Excellent } \\
\text { (4) }\end{array}$ \\
\hline 1. & Materials for the ASERT Tool are present and sufficient. & & & & \\
\hline 2. & $\begin{array}{l}\text { The facilitator used the materials during the creation of the } \\
\text { ASERT exercise. }\end{array}$ & & & & \\
\hline 3. & $\begin{array}{l}\text { The facilitator gave a complete introduction of the reason for } \\
\text { conducting an ASERT exercise and showed an example to the } \\
\text { group. }\end{array}$ & & & & \\
\hline 4. & $\begin{array}{l}\text { The facilitator clearly emphasized that the girls' answers were } \\
\text { not about their personal experiences; they should not mention } \\
\text { any names; and she asked if participants understood this. }\end{array}$ & & & & \\
\hline 5. & $\begin{array}{l}\text { The facilitator gave clear instructions to the girls on how to } \\
\text { write down the type of people girls have sex with. }\end{array}$ & & & & \\
\hline 6. & $\begin{array}{l}\text { The facilitator assisted the girls in identifying - for each person } \\
\text { type they named - all of the reasons girls engage in sex with } \\
\text { that type. }\end{array}$ & & & & \\
\hline 7. & $\begin{array}{l}\text { The facilitator assisted the girls to rank - for each person type - } \\
\text { the reasons girls engage in sex with that type. }\end{array}$ & & & & \\
\hline 8. & $\begin{array}{l}\text { The facilitator gave clear instructions to the girls on how they } \\
\text { should place the different types of people along the first } \\
\text { column of the ASERT grid. }\end{array}$ & & & & \\
\hline 9. & $\begin{array}{l}\text { The facilitator gave clear instructions to the girls on how they } \\
\text { should place the rank ordered reasons across the row for each } \\
\text { person type in the ASERT grid. }\end{array}$ & & & & \\
\hline 10. & $\begin{array}{l}\text { The facilitator assisted a representative from each group to } \\
\text { come forward and discuss the results of their ASERT Grid. }\end{array}$ & & & & \\
\hline 11. & $\begin{array}{l}\text { The facilitator effectively led a discussion at the end of the } \\
\text { exercise, which strengthened girls' understanding of why girls } \\
\text { engage in sex with different types of people. }\end{array}$ & & & & \\
\hline 12. & $\begin{array}{l}\text { The facilitator was effective in enabling all girls to express their } \\
\text { opinions and participate. }\end{array}$ & & & & \\
\hline 13. & $\begin{array}{l}\text { The facilitator made sure the "Facilitator's Recording of ASERT } \\
\text { Tool Features Grid" was completed. }\end{array}$ & & & & \\
\hline
\end{tabular}


IMAGEN

1 Dag Hammarskjold Plaza

$3^{\text {rd }}$ Floor

New York, New York 10017

IMAGEN-network.org 